\title{
Ni-Cr-Al 合金のセル状析出に及ぼす添加元素の影響
}

\author{
植田茂紀 $* 1$, 清水哲也 *1，梶原正憲 $* 2$
}

\section{Influence of Additional Alloying Elements on Cellular Precipitation in Ni-Cr-Al Alloys}

\author{
Shigeki Ueta, Tetsuya Shimizu, and Masanori Kajihara
}

\section{Synopsis}

A Ni-38 mass\% Cr-3.8 mass\% Al alloy possesses higher hardness and tensile strength than conventional Ni-base alloys. Such excellent properties are attributed to the discontinuous or cellular precipitation of the Cr-rich solid-solution $(\alpha)$ phase with the body-centered cubic (bcc) structure combined with the continuous precipitation of the $N i_{3} A l(\gamma$ ') phase with the $\mathrm{LI}_{2}$ structure from the Ni-rich solid-solution $(\gamma)$ phase with the face-centered cubic (fcc) structure. Due to the cellular precipitation, the untransformed matrix of the $\gamma$ phase is transformed into the cell consisting of the $\gamma$ and $\alpha$ lamellae dispersed with fine $\gamma$ ' particles. Since the growth of the cell is controlled by the boundary diffusion along the moving boundary between the cell and the untransformed matrix, it occurs rather fast. In such a case, it is not easy to realize the uniformly transformed cell over the whole area of the alloy with a large size. In order to find the alloying element inhibiting the growth of the cell, the influence of Mo, W and Fe on the kinetics of the cellular precipitation was experimentally observed using $\mathrm{Ni}-\mathrm{Cr}$-Al alloys with 35-36 mass\% Cr and 3.8 mass\% Al containing 1-2 mass\% Mo, 1-2 mass\% W or 5 mass\% Fe. According to the observation, the overall growth of the cell is decelerated by Mo and W, but accelerated by Fe. Furthermore, the influence is more remarkable for Mo than for W. Thus, Mo is one of the most effective alloying elements suppressing the growth of the cell.

\section{1. 緒 言}

Ni-38 mass\%Cr-3.8 mass\%Al 合金を $\gamma$ 単相領域において 固溶化加熱処理した後 $\left(\gamma+\gamma^{\prime}+\alpha\right)$ 三相領域で時効加熱処 理すると, $\gamma^{\prime}$ 相の微細粒子が $\gamma$ 母相に均一に分散した $\left(\gamma+\gamma^{\prime}\right)$ 二相組織が連続析出により生成した後, 層状の $\gamma$ 相と $\alpha$ 相から成る $(\gamma+a)$ 七ル状組織が不連続析出により 生成する。 その際, $\left(\gamma+\gamma^{\prime}\right)$ 二相組織中の $\gamma^{\prime}$ 相は $(\gamma+\alpha)$ セル状組織の内部に微細な分散粒子として取り达まれる. ここで, $\gamma$ 相は面心立方構造 (fec) の Ni 固溶体相であり, $a$ 相は体心立方構造 (bcc) の Cr 固溶体相であり， $\gamma^{\prime}$ 相は $\mathrm{L}_{2}$ 構造の $\mathrm{Ni}_{3} \mathrm{Al}$ である. 既に前報で報告したように ${ }^{1)}{ }^{2)}$, このような $\left(\gamma+\gamma^{\prime}+\alpha\right)$ セル状組織を有する $\mathrm{Ni}-38 \mathrm{Cr}-3.8 \mathrm{Al}$ 合金は, $700 \mathrm{HV}$ 程度の硬さと $2 \mathrm{GPa}$ 以上の引張強さを兼 ね備えた高強度合金である。また，耐食性にも優れる同 非磁性合金は, 締結部品用材料, 金型用材料, 軸受用材
料などへの応用が検討されている.

上述のように, Ni-38Cr-3.8Al 合金では時効加熱処理の 初期段階における $\gamma^{\prime}$ 相の生成により $\mathrm{Ni}$ と $\mathrm{Al}$ が消費され るため, $\gamma$ 母相の $\mathrm{Cr}$ 濃度が高くなる。このような $\mathrm{Cr}$ 濃 度の増加は, $(\gamma+\alpha)$ セル状組織の生成のための駆動力を 高めることになる。 また, 同駆動力の増加は時効温度が 高くなると顕著になる ${ }^{2)}{ }^{3)}$. このため, Ni-38Cr-3.8Al 合 金の時効硬化速度は, 約 $700{ }^{\circ} \mathrm{C}$ 以上の高温度域において 従来型の $\mathrm{Ni}$ 基超合金よりも著しく大きい4). ところで, 形状の大きな $\mathrm{Ni}-38 \mathrm{Cr}-3.8 \mathrm{Al}$ 合金では, 固溶化加熱処理後 の冷却過程において，合金表面部の冷却速度が大きくて も合金中心部の冷却速度はかなり小さくなる。このよう な状況では, 合金中心部において $\left(\gamma+\gamma^{\prime}+\alpha\right)$ セル状組織 の生成が生じ，時効硬化する危険性がある ${ }^{1)}$. 合金中心 部における時効硬化は，冷却過程における合金の折損を 誘発したり， 部品製造時の切断加工やドリル加工を困難 
にする、しかし，残念ながら，現有の製造設備では， Ni$38 \mathrm{Cr}-3.8 \mathrm{Al}$ 合金のセル状組織の生成を抑制するような冷 却条件の実現は困難である.

ところで, 不連続析出によるセル状組織の成長速度は, 合金成分の添加に依存して変化する ${ }^{5), 6)}$ そそこで， Ni$38 \mathrm{Cr}-3.8 \mathrm{Al}$ 合金のセル状組織の成長を抑制するような添 加元素が見つかれば，形状が大きくても合金中心部で時 効硬化の起りにくい製品の開発が可能となる。しかし, $\mathrm{Ni}-\mathrm{Cr}-\mathrm{Al}$ 三元系はもちろんのこと $\mathrm{Ni}-\mathrm{Cr}$ 二元系において さえも, セル状組織の成長挙動に及ぼす添加元素の影響 に対する信頼性の高い研究報告は残念ながら存在しない のが現状である。そこで, 本研究では, 第 4 元素添加に よるセル状組織の成長抑制の可能性を検討するため, Mo, $\mathrm{W}$ および Fe を候補添加元素として選定し， Ni-Cr-Al 合金 のセル状組織の成長挙動に及ぼすこれらの添加元素の影 響を調査した。

\section{2. 実験方法}

\section{1 合金組成の選定}

$\mathrm{Ni}-38 \mathrm{Cr}-3.8 \mathrm{Al}$ 合金の $\gamma$ 相に対する $\alpha$ 相の固溶温度は約 $1440 \mathrm{~K}$ とかなり高くなっている。そこで，開発合金の実 用性の向上を目指し，上記固溶温度が $1400 \mathrm{~K}$ 以下となる 成分範囲で Mo, W および $\mathrm{Fe}$ の添加を検討した。そこで, 状態図計算ソフト Thermo-Calc と Ni 基合金熱力学デー夕 ベース Ni-Data Ver.6（Thermotech Ltd.）を用い， $a$ 相の固 溶温度に及ぼす Mo，W および Feの影響を計算した。そ の結果を Fig.1 に示す。ここで, Fig.1(a), (b) および (c) は, それぞれ Ni-38Cr-3.8Al- $X$ 四元系 $(X: \mathrm{Mo}, \mathrm{W}, \mathrm{Fe})$ の計算 状態図の縦断面図を表している。いずれの添加元素にお いても濃度が大きくなると上記固溶温度は高くなる。し かし，温度上昇の程度は，Wで顕著であるが Mo, Feで は比較的緩やかである。Fig.2に，種々の Cr 濃度に対し て計算した $\alpha$ 相固溶温度と Mo,W,Fe 濃度の関係を示す。

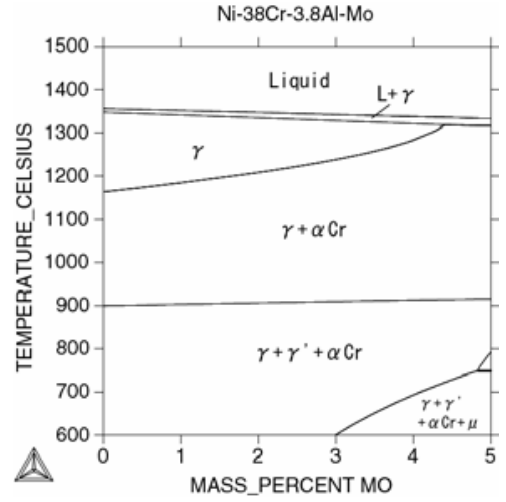

(a) Mo

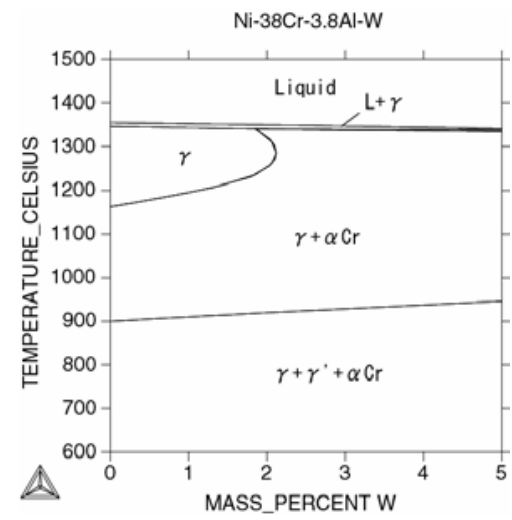

(b) W

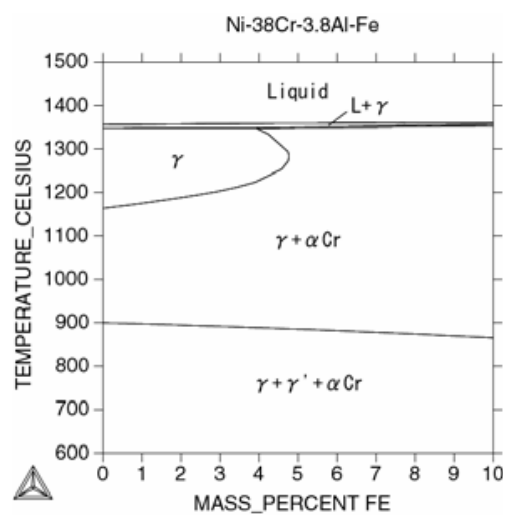

(c) $\mathrm{Fe}$

Fig.1. Vertical sections of the phase diagram in the Ni-38Cr-3.8Al- $X$ system calculated by Thermo-Calc for (a) $X=$ Mo, (b) $X=$ W and (c) $X$ $=\mathrm{Fe}$.

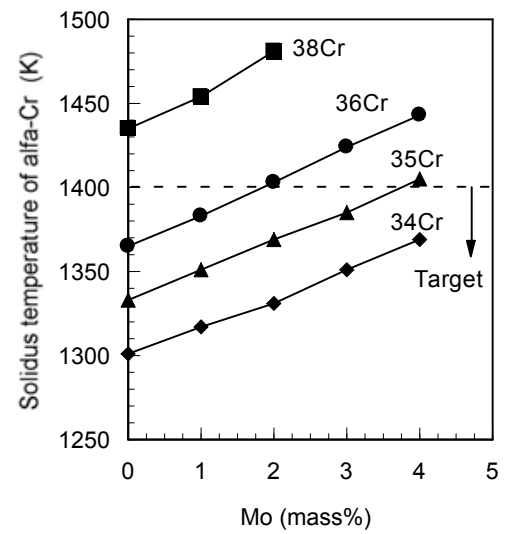

(a) Mo

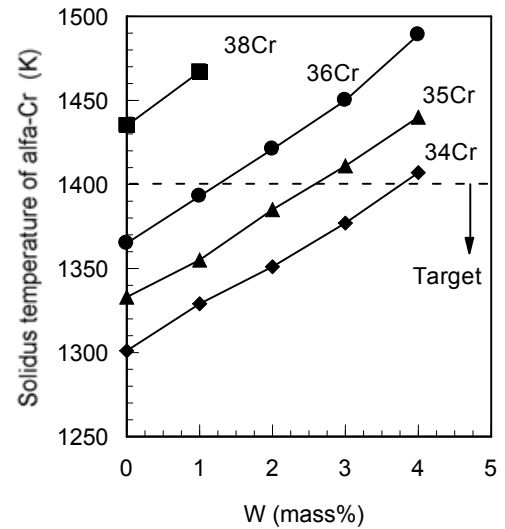

(b) W

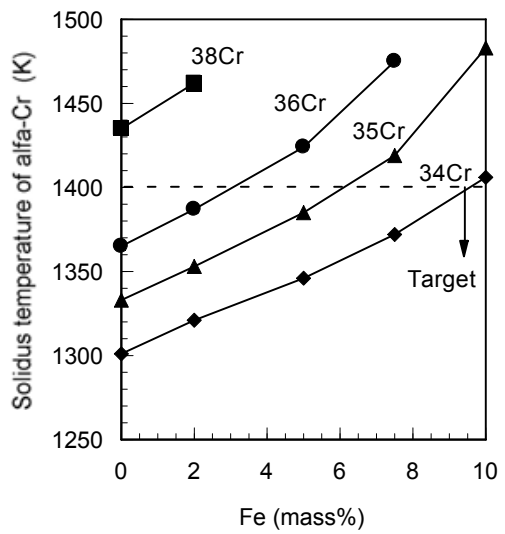

(c) $\mathrm{Fe}$

Fig.2. The solubility limit of the $a$ phase in the $y$ phase versus the concentration of element $X$ calculated by Thermo-Calc at various $\mathrm{Cr}$ concentrations for (a) $X=\mathrm{Mo}$, (b) $X=\mathrm{W}$ and (c) $X=\mathrm{Fe}$. 


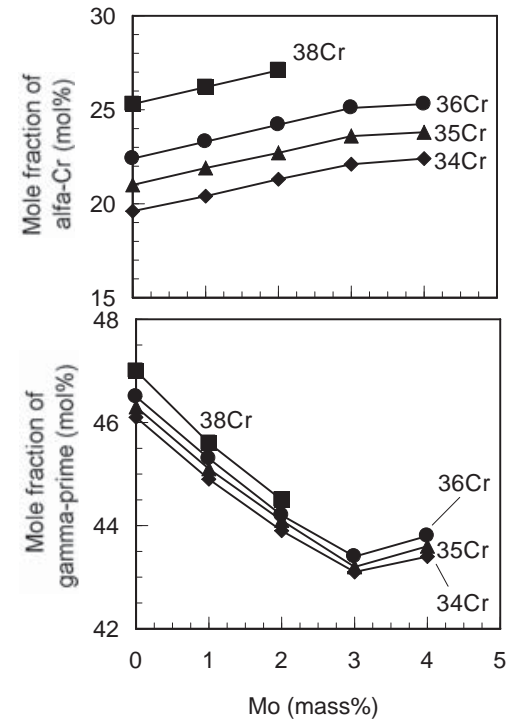

(a) Mo

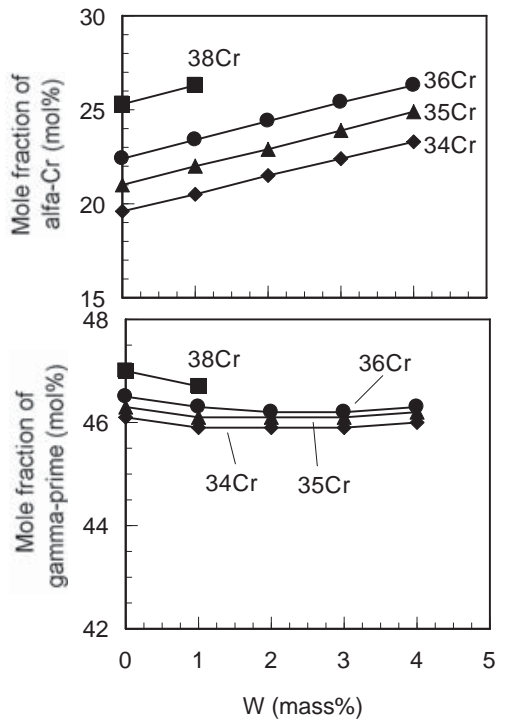

(b) W

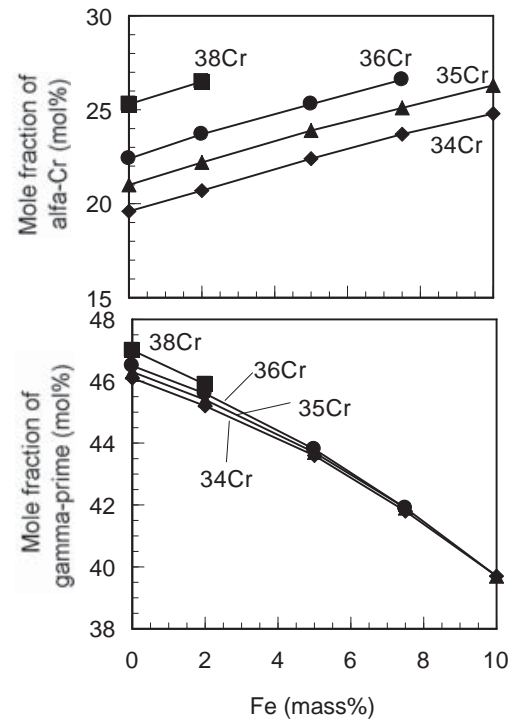

(c) $\mathrm{Fe}$

Fig.3. The mole fractions of the $a$ and $Y^{\prime}$ phases versus the concentration of element $X$ calculated by Thermo-Calc at $873 \mathrm{~K}$ for (a) $X=$ Mo, (b) $X=\mathrm{W}$ and (c) $X=\mathrm{Fe}$.

$\mathrm{Mo}, \mathrm{W}$ および $\mathrm{Fe}$ の濃度が大きくても， $\mathrm{Cr}$ 濃度が小さく なると上記固溶温度は低下する。 そこで, Fig.2の結果に 基づき， Mo, $\mathrm{W}$ 抢よび $\mathrm{Fe}$ の添加を $1 \mathrm{mass} \%$ 以上に設定 するために, Cr 濃度を 36 mass\% 以下とすることとした。 一方，Fig.3(a)，(b) および (c)は，それぞれはFig.2(a)， (b) 捛よび (c) の組成範囲の Ni-Cr-3.8Al- $X$ 四元系合金に 対する $873 \mathrm{~K}$ における $a$ 相および $\gamma^{\prime}$ 相のモル分率の組 成依存性を示す。 $a$ 相のモル分率は $\mathrm{Cr} ， \mathrm{Mo}, \mathrm{W}$ 抢よび $\mathrm{Fe}$ の濃度が大きくなると単調に増加する。これに対し， $\gamma^{\prime}$ 相のモル分率は, $\mathrm{Cr}$ 濃度が大きくなると増加するが, $\mathrm{Mo}$ や $\mathrm{Fe}$ の濃度大きくなると打打む秋減少する。しかし， $\mathrm{W}$ 濃度が変化しても， $\gamma^{\prime}$ 相のモル分率はほぼ一定となっ ている，そこで， $a$ 相と $\gamma$ 相のモル分率をほほ一定值に 揃えるために, Ni-Cr-3.8Al- $X$ 四元系合金に打ける Mo, $\mathrm{W}$ および $\mathrm{Fe}$ の最大濃度をそれぞれ 2 mass $\%, 2$ mass \% お よび 5 mass\% とした.

\section{2 合金試料の作製}

2.1 節に抄いて決定した 5 種類の Ni-Cr-Al- $X$ 四元系合金 の配合組成を Table 1 に示す。 以下では, それぞれ Base 合金, $1 \mathrm{Mo}$ 合金, $2 \mathrm{Mo}$ 合金, $1 \mathrm{~W}$ 合金，2W 合金抒よび $5 \mathrm{Fe}$ 合金と略記することにする。また，Table 1 には， $\gamma$ 相に対する $a$ 相の固溶温度や $873 \mathrm{~K}$ に扔ける $a$ 相扮よび $\gamma^{\prime}$ 相のモル分率に対する計算值を示す，Mo，W 抄よび $\mathrm{Fe}$ 添加合金における $a$ 相掞よび $\gamma$ 相のモル分率は, Base 合金における $25 \mathrm{~mol} \%$ 拉よび $47 \mathrm{~mol} \%$ よりやや低いもの の, $23 \mathrm{~mol} \%$ 抢よび 44 〜 $46 \mathrm{~mol} \%$ とほぼ一定になって いる。これらの合金を真空䨌囲気の高周波溶解法により， $50 \mathrm{~kg}$ の鋳塊として溶製した。この鋳塊を $1473 \mathrm{~K}$ で 57.6 $\mathrm{ks}$ の均質化加熱処理した後，熱間鍛造抢よび熱間圧延よ り直径が $16 \mathrm{~mm}$ の棒状試料にした，同棒状試料を一定温 度で $1.8 \mathrm{ks}$ の固溶化加熱処理した後, 水冷した。その際, 固溶化温度は, Base 合金では $1473 \mathrm{~K}$ であり，その他の 合金では $1423 \mathrm{~K}$ となっている。これらの固溶加熱試料を $773 \sim 1073 \mathrm{~K}$ の温度範囲で $0.9 \sim 180 \mathrm{ks}$ 等温時効加熱処

Table 1. Chemical compositions of the Ni-Cr-Al- $X$ alloys measured in mass $\%$.

\begin{tabular}{|c|c|c|c|c|c|c|c|c|c|c|c|}
\hline \multirow[t]{2}{*}{ Alloy } & \multirow[t]{2}{*}{ C } & \multirow[t]{2}{*}{$\mathrm{Cr}$} & \multirow[t]{2}{*}{$\mathrm{Al}$} & \multirow[t]{2}{*}{ Mo } & \multirow[t]{2}{*}{ W } & \multirow[t]{2}{*}{$\mathrm{Fe}$} & \multirow[t]{2}{*}{ B } & \multirow[t]{2}{*}{$\mathrm{Ni}$} & \multirow{2}{*}{$\begin{array}{c}a \text { Cr Solidus } \\
(\mathrm{K})\end{array}$} & \multicolumn{2}{|c|}{$\begin{array}{c}\text { at } 873 \mathrm{~K} \\
(\mathrm{~mol} \%)\end{array}$} \\
\hline & & & & & & & & & & $a \mathrm{Cr}$ & $y^{\prime}$ \\
\hline Base & 0.02 & 38.1 & 3.8 & - & - & - & 0.003 & \multirow{6}{*}{ Bal. } & 1435 & 25.3 & 47.0 \\
\hline $1 \mathrm{Mo}$ & 0.01 & 36.1 & 3.8 & 1.0 & - & - & 0.003 & & 1383 & 23.3 & 45.3 \\
\hline $2 \mathrm{Mo}$ & 0.02 & 34.9 & 3.8 & 2.0 & - & - & 0.003 & & 1369 & 22.7 & 44.1 \\
\hline $1 \mathrm{~W}$ & 0.02 & 35.9 & 3.8 & - & 1.0 & - & 0.003 & & 1393 & 23.4 & 46.3 \\
\hline $2 W$ & 0.01 & 35.2 & 3.9 & - & 2.1 & - & 0.003 & & 1385 & 22.9 & 46.1 \\
\hline $5 \mathrm{Fe}$ & 0.01 & 35.2 & 3.9 & - & - & 5.02 & 0.003 & & 1385 & 23.9 & 43.7 \\
\hline
\end{tabular}


理した後, 空冷した. 続いて各熱処理試料の切断面を鏡 面機械研磨し， $60 \mathrm{ml}$ のメタール， $30 \mathrm{ml}$ の塩酸および $3 \mathrm{~g}$ の塩化第二鉄を配合した腐食液で化学腐食した後, ミ クロ組織を光学顕微鏡や走査型電子顕微鏡により観察し た。

\section{3. 結 果}

\section{1 ミクロ組織}

固溶加熱処理した種々の合金の光学顕微鏡によるミク ロ組織を Fig.4に示す。 $2 \mathrm{Mo}$ 合金および $2 \mathrm{~W}$ 合金, $5 \mathrm{Fe}$ 合 金では未固溶の $\alpha$ 相がわずかに認められるが, ほとんど は $\gamma$ 単相組織となっている。 また, $\gamma$ 母相の結晶粒径は

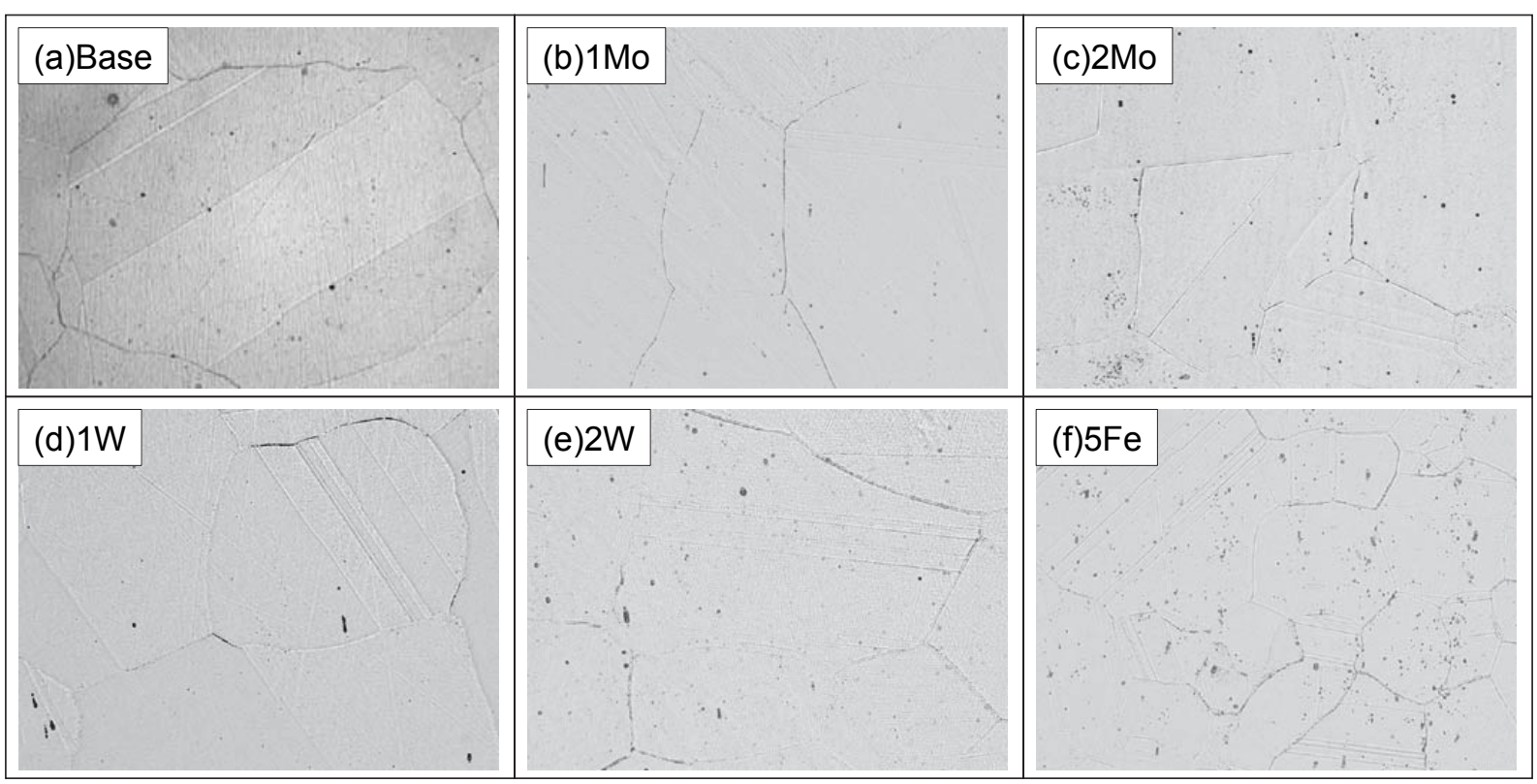

$200 \mu \mathrm{m}$

Fig.4. Optical micrographs of the Ni-Cr-Al-X alloys solution-treated for $1.8 \mathrm{ks}$ at (a) $1473 \mathrm{~K}$ and (b)-(f) $1423 \mathrm{~K}$ : (a) Base alloy, (b) 1 Mo alloy, (c) 2Mo alloy, (d) 1W alloy, (e) 2W alloy and (f) 5 Fe alloy.

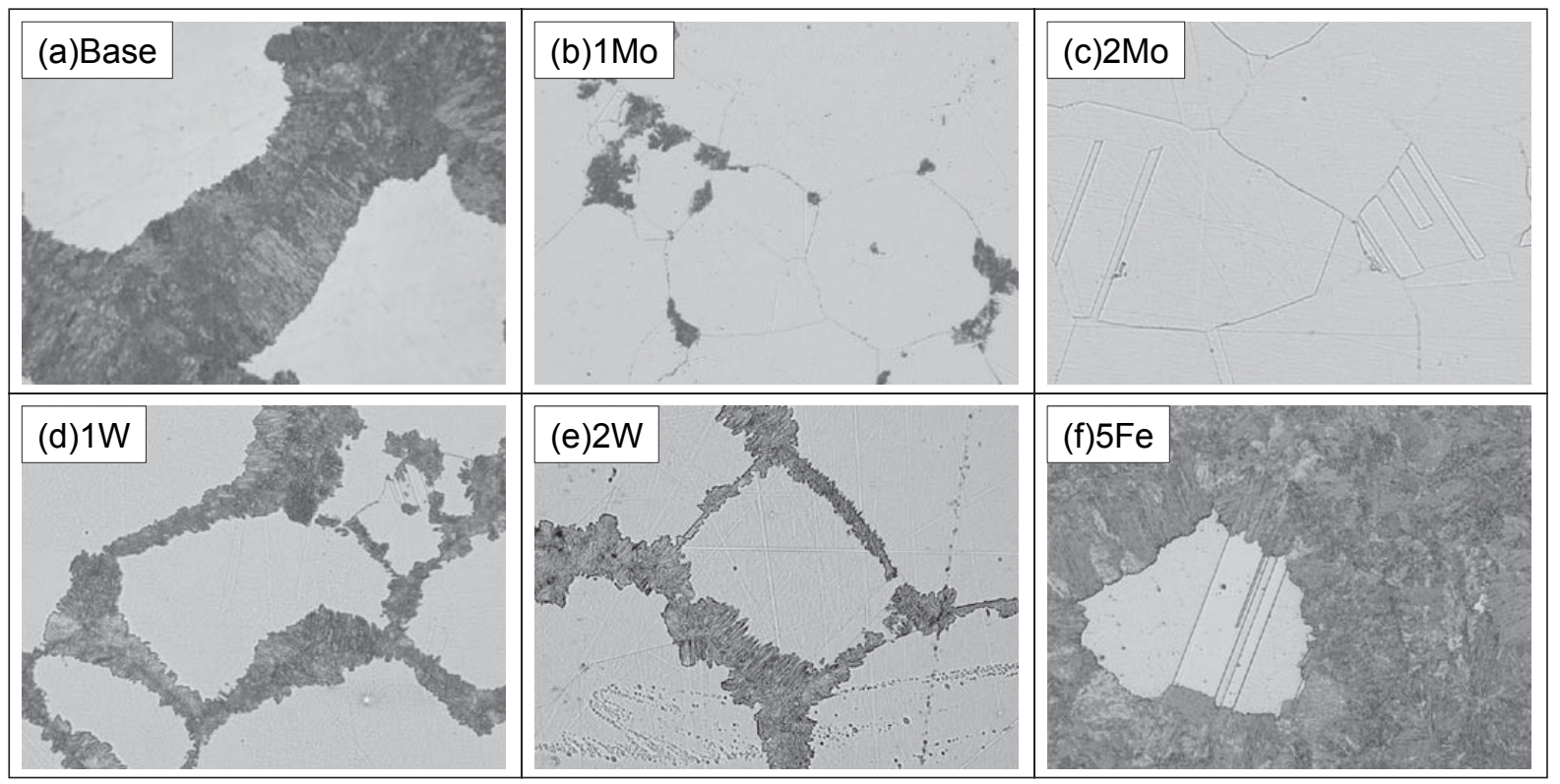

$200 \mu \mathrm{m}$

Fig.5. Optical micrographs of the Ni-Cr-Al- $X$ alloys aged at $873 \mathrm{~K}$ for $28.8 \mathrm{ks}$ : (a) Base alloy, (b) 1 Mo alloy, (c) 2Mo alloy, (d) $1 \mathrm{~W}$ alloy, (e) $2 \mathrm{~W}$ alloy and (f) $5 \mathrm{Fe}$ alloy. 


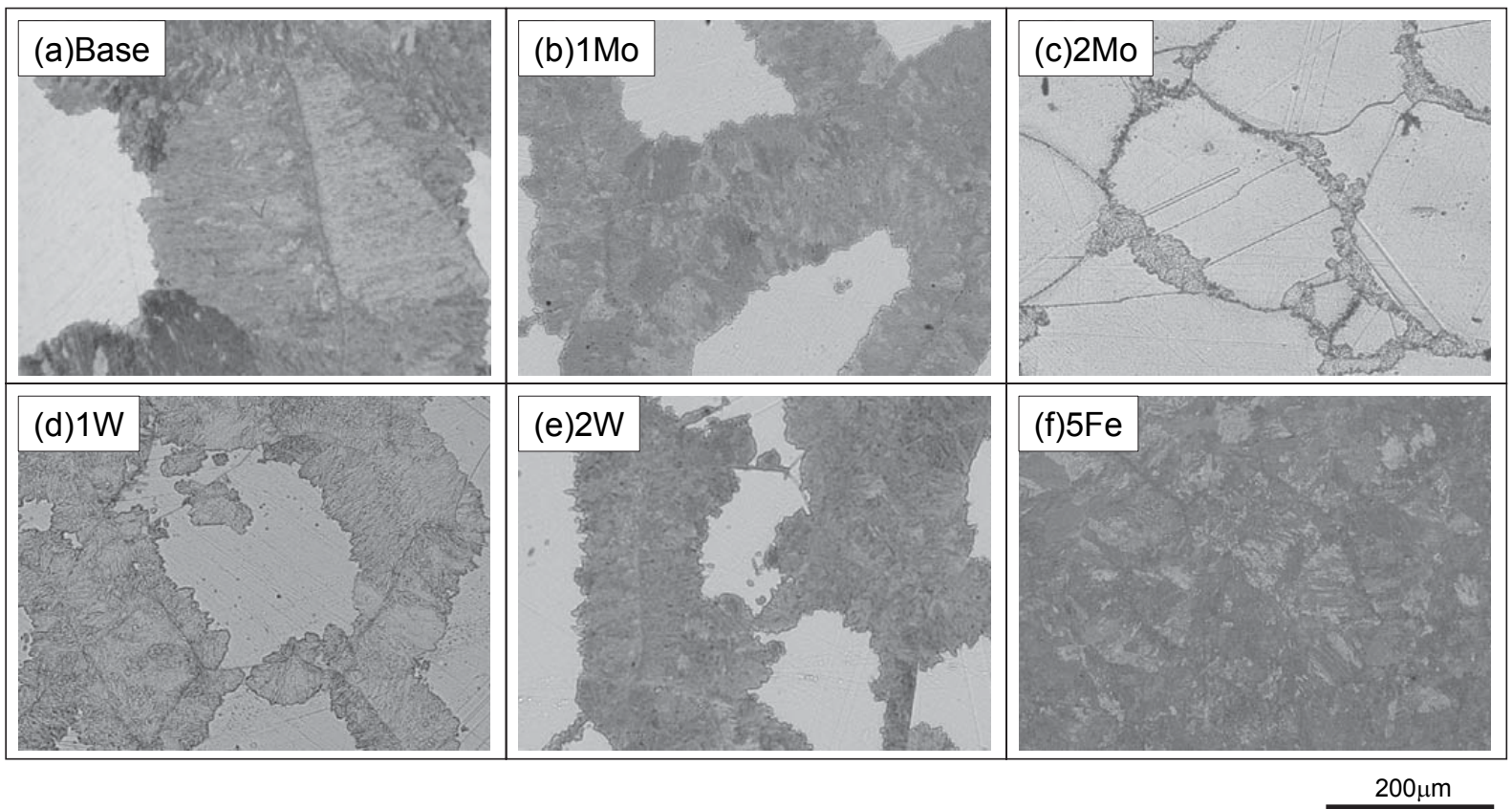

Fig.6. Optical micrographs of the Ni-Cr-Al- $X$ alloys aged at $973 \mathrm{~K}$ for $3.6 \mathrm{ks}$ : (a) Base alloy, (b) 1 Mo alloy, (c) 2Mo alloy, (d) $1 \mathrm{~W}$ alloy, (e) $2 \mathrm{~W}$ alloy and (f) $5 \mathrm{Fe}$ alloy.

$200 \sim 400 \mu \mathrm{m}$ 程度となっている.

一方, $873 \mathrm{~K}$ で $28.8 \mathrm{ks}$ の時効加熱処理した種々の合金 のミクロ組織を Fig.5に示す。2Mo 合金を除くほとんど の合金において， $\gamma$ 母相の粒界に沿ってセル状組織が生 成している。また，粒界に垂直な方向におけるセル状組 織の幅は, Base 合金や $5 \mathrm{Fe}$ 合金で大きく, $1 \mathrm{Mo}$ 合金, $1 \mathrm{~W}$ 合金および $2 \mathrm{~W}$ 合金で小さくなっている

また， $973 \mathrm{~K} て ゙ 3.6 \mathrm{ks}$ の時効加熱処理した種々の合金 のミクロ組織を Fig.6 に示す. Fig.5 の $873 \mathrm{~K}$ におけるよ りも時効時間が短いにも係らず，七ル状組織の体積率は Fig.6の $973 \mathrm{~K}$ において大きくなっている. 特に, $2 \mathrm{Mo}$ 合金は, Fig.5(c)の $873 \mathrm{~K}$ では $\gamma$ 単相組織であったが,

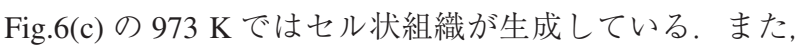
Fig.6(f)の 5Fe 合金では，セル状組織が試料全面を覆って いる.

\section{2 セル状組織の成長挙動}

Fig.5 や Fig.6の時効加熱試料で観察されたセル状組織 を Fig.7 に模式的 7)に示す. 同図のように，切断面上の セル状組織の最も幅の広い箇所において，七ル状組織の 先進移動粒界と $\gamma$ 母相の粒界との距離 $w[\mathrm{~m}]$ を各切断面の ミクロ組織に対し 40 箇所以上測定し, 平均值を求めた。 以下では，同平均值をただ単に $w$ と記述することにする。 時効温度 $873 \mathrm{~K}$ および $973 \mathrm{~K}$ に対する移動距離 $w$ の時効 時間依存性をそれぞれ Fig.8(a) および (b) に示す。移動距 離 $w$ は時効時間が長くなると単調に増加する。 $873 \mathrm{~K} に$
おける移動距離の時間依存の傾き, すなわちセル成長速 度は，Base 合金と $5 \mathrm{Fe}$ 合金で同程度であるが，1W 合金 と $2 \mathrm{~W}$ 合金で約 $1 / 3$ 程度, $1 \mathrm{Mo}$ 合金と $2 \mathrm{Mo}$ 合金で約 $1 / 10$ とかなり小さくなっている。また，973 Kにおけるセル 成長速度は, $1 \mathrm{~W}$ 合金，2W 合金および $1 \mathrm{Mo}$ 合金は Base 合金の約 $1 / 2$ 程度, $2 \mathrm{Mo}$ 合金で約 $1 / 10$ となっている。なお, $5 \mathrm{Fe}$ 合金では, $973 \mathrm{~K}$ で $1.8 \mathrm{ks}$ の時効加熱処理でもセル状 組織が試料全面を覆ってしまうため，先進移動粒界の移 動距離を測定することができなかった。

Fig.8のような実験結果において，各時効温度および時 効時間におけるセル成長速度 $v[\mathrm{~m} / \mathrm{s}]$ を算出した。 その結 果を Fig.9 に示す。いずれの合金においても，成長速度 $v$

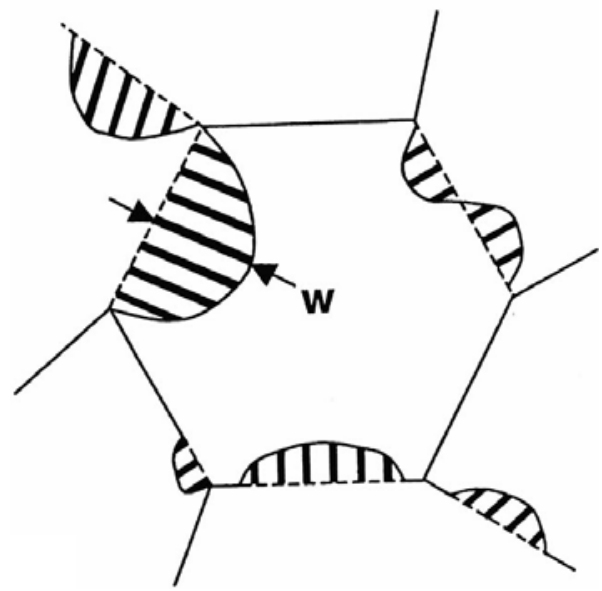

Fig.7. Schematic microstructure of cellular precipitation indicating the migration distance $w$ of the moving boundary ${ }^{7}$. 


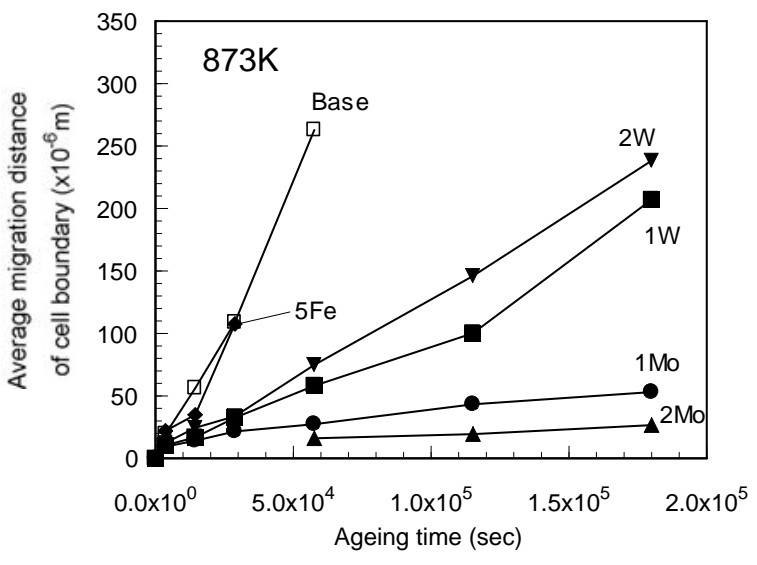

(a) $873 \mathrm{~K}$

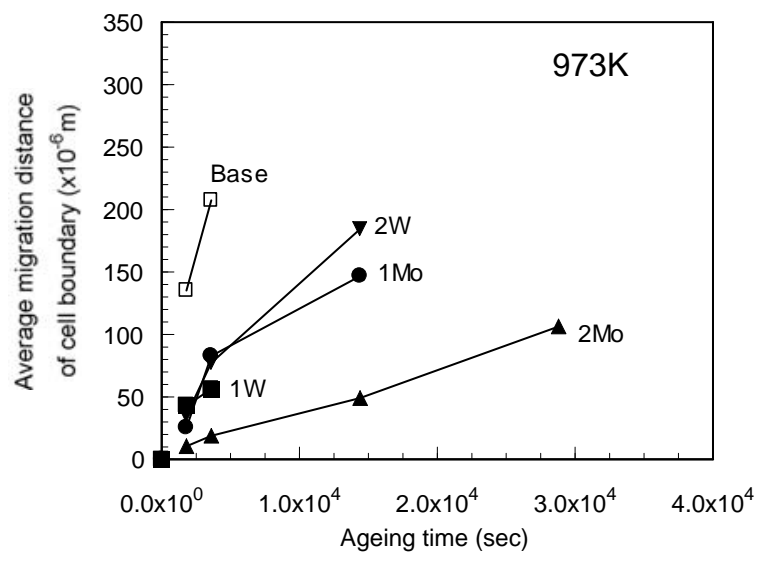

(b) $973 \mathrm{~K}$

Fig.8. The migration distance $<w>$ of the moving boundary versus the ageing time at (a) $873 \mathrm{~K}$ and (b) $973 \mathrm{~K}$.

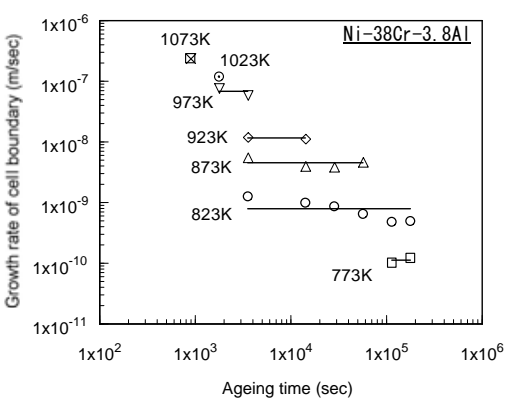

(a)Base

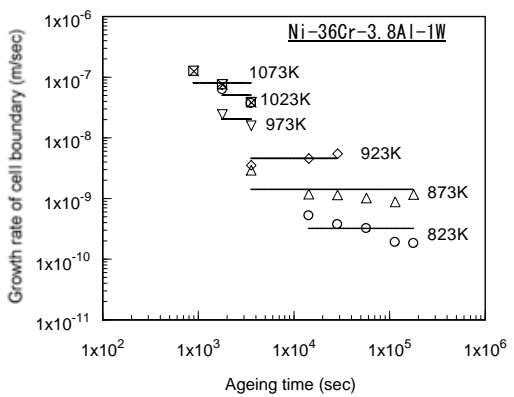

(d) $1 \mathrm{~W}$

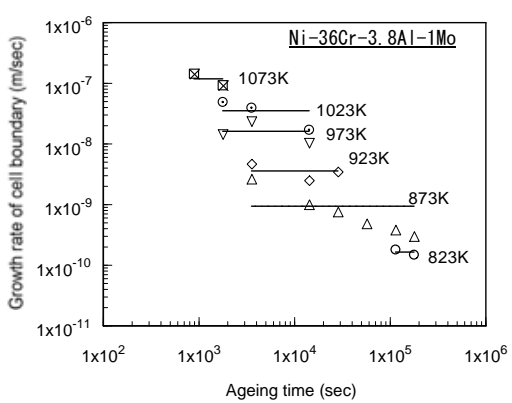

(b) $1 \mathrm{Mo}$

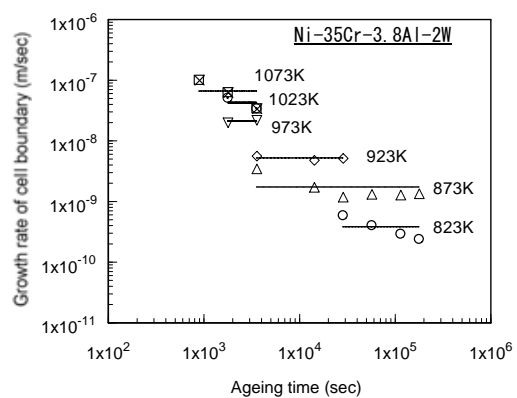

(e) $2 \mathrm{~W}$

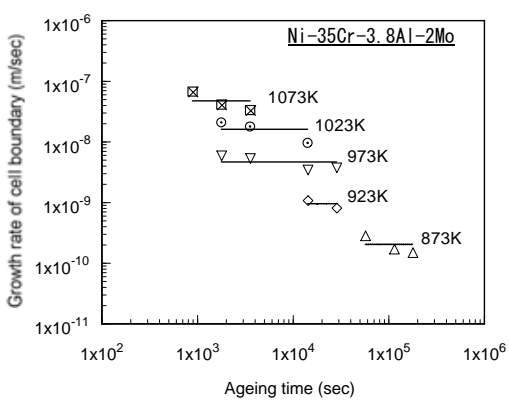

(c) $2 \mathrm{Mo}$

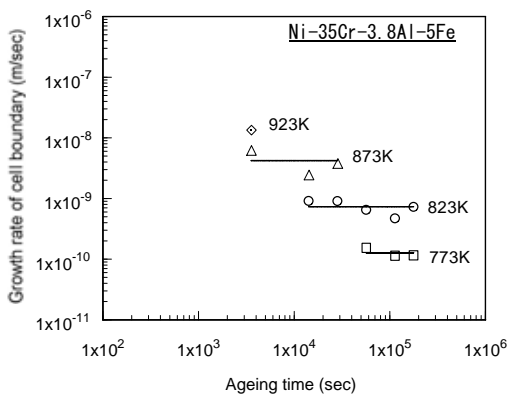

(f) $5 \mathrm{Fe}$

Fig.9. The migration rate $<v>$ of the moving boundary versus the ageing time at various temperatures for (a) Base alloy, (b) 1 Mo alloy, (c) 2Mo alloy, (d) 1W alloy, (e) 2W alloy and (f) 5Fe alloy.

は時効時間によらずほぼ一定となっている。また，各合 金の成長速度 $v$ は，時効温度が高くなると単調に増加す る.

種々の合金に対する成長速度と時効温度の関係を Fig.10に示す。セル成長速度は $1 \mathrm{Mo}$ 合金抢よび $2 \mathrm{Mo}$ 合 金ではMo 濃度が高くなると単調に減少するが，1W 合金 および $2 \mathrm{~W}$ 合金では 1 mass\% 以下において W 濃度が高く なると減少するものの 1 mass\% 以上に打いては W 濃度依 存が小さくなる。これに対し， $5 \mathrm{Fe}$ 合金では，七ル成長 速度がBase 合金とほぼ等しくなっている。また，Fig.10
には, $\mathrm{Ni}-\mathrm{Cr}$ 二元系合金に対する同様の結果 ${ }^{8)}$ を重ね合せ て示す.これらの $\mathrm{Ni}-\mathrm{Cr}$ 二元系合金に扮けるセル成長速 度は，本研究のいずれの合金よりも小さくなっている。

\section{3 セル状組織のラメラー間隔}

$973 \mathrm{~K}$ で時効加熱処理した種々の合金の走査型電子顕 微鏡によるセル内部組織を Fig.11に示す。同図に扔いて, 白いコントラストの薄い板は $\alpha$ 相である。また， $a$ 相板 に挟まれた $\gamma$ 相は化学腐食により溶解してしまうため, 各 $a$ 相板の間に隙間が生成する。このラメラー間隔を 40 


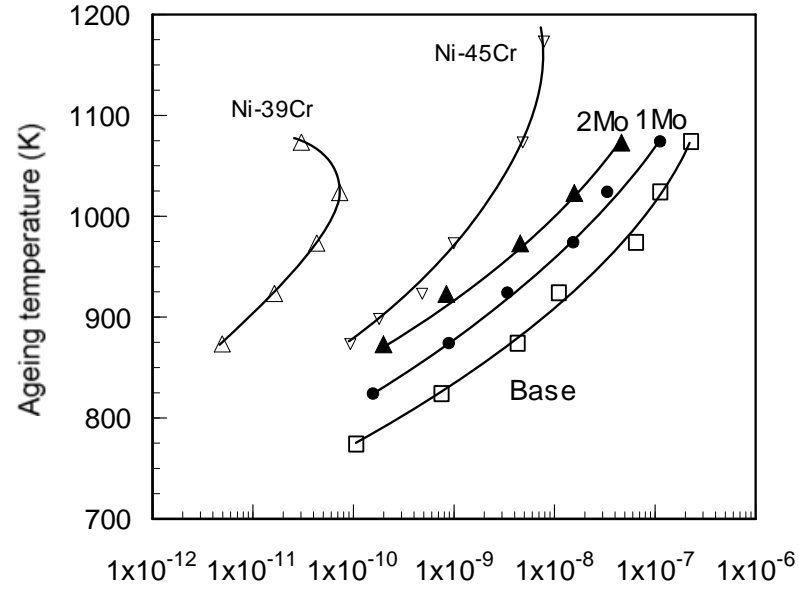

Average growth rate of cell boundary $(\mathrm{m} / \mathrm{sec})$

(a) $1 \mathrm{Mo}, 2 \mathrm{Mo}$

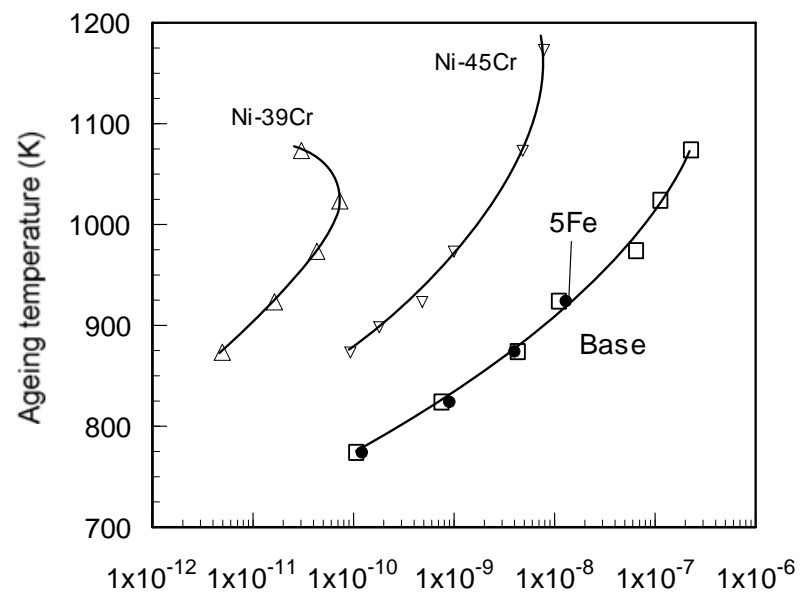

Average growth rate of cell boundary $(\mathrm{m} / \mathrm{sec})$

(c) $5 \mathrm{Fe}$

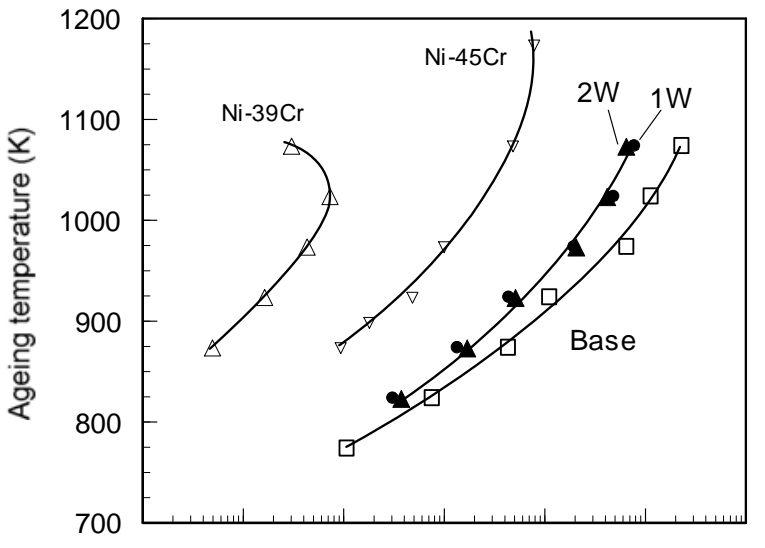

$1 \times 10^{-12} 1 \times 10^{-11} 1 \times 10^{-10} 1 \times 10^{-9} \quad 1 \times 10^{-8} \quad 1 \times 10^{-7} \quad 1 \times 10^{-6}$

Average growth rate of cell boundary $(\mathrm{m} / \mathrm{sec})$

(b) $1 \mathrm{~W}, 2 \mathrm{~W}$

Fig.10. The ageing temperature versus the migration rate $<\mathrm{v}>$ of the moving boundary for (a) $1 \mathrm{Mo}$ and $2 \mathrm{Mo}$ alloys, (b) 1W and 2W alloys and (c) $5 \mathrm{Fe}$ alloy.

個以上のセルに対し測定し, 平均值 $\lambda_{0}$ を算出した。 また, 同平均值 $\lambda_{0}$ に対し次式のような補正 9)を行い，平均ラメ ラー間隔 $\lambda$ を求めた。

$$
\lambda=0.5 \lambda_{0} \text {. }
$$

各時効加熱温度で同様に測定した結果を Fig.12に示す。 ラメラー間隔はほとんどの時效温度において Mo, W 抢よ び Fe の添加により増加する，このような影響は，特に Moにおいて顕著である。しかし， Ni-45Cr 二元系合金 ${ }^{3)}$ の $873 \sim 1173 \mathrm{~K}$ に扔ける $\lambda=200 \times 10^{-9} \sim 500 \times 10^{-9} \mathrm{~m}$ に比較すると 1 桁程度小さくなっている.
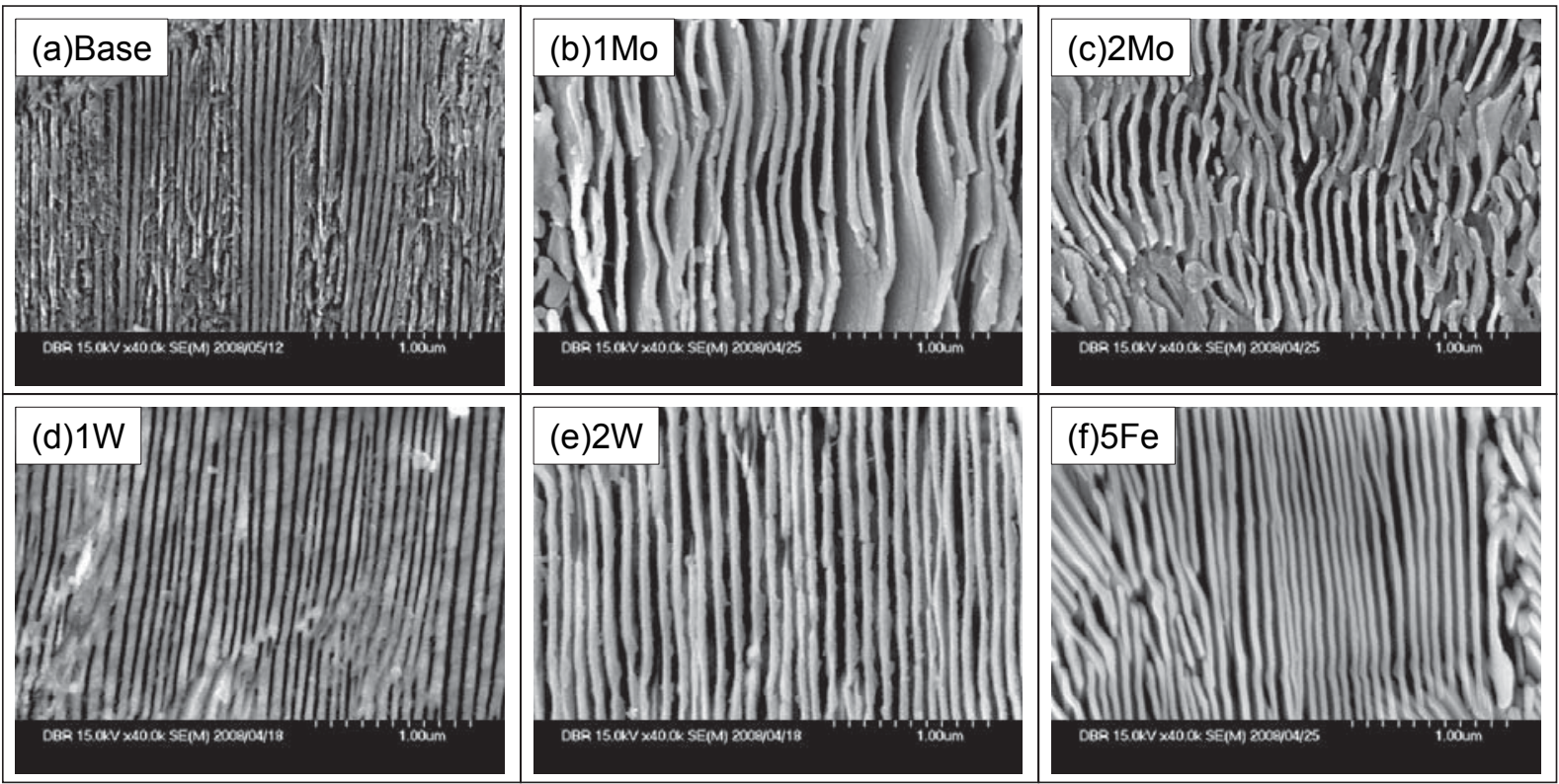

Fig.11. Microstructure of cell by scanning electron microscopy at an ageing temperature of $973 \mathrm{~K}$ for (a) Base alloy, (b) 1 Mo alloy, (c) 2 Mo alloy, (d) 1W alloy, (e) 2W alloy and (f) 5Fe alloy. 


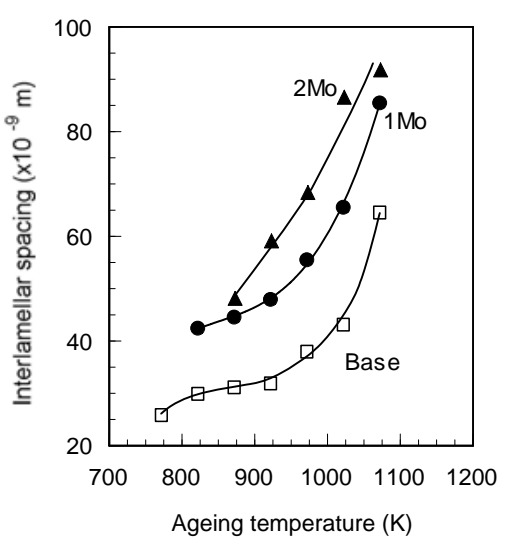

(a) $1 \mathrm{Mo}, 2 \mathrm{Mo}$

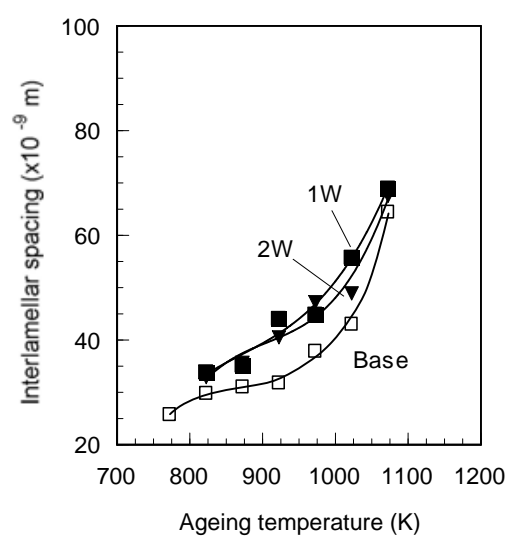

(b) $1 \mathrm{~W}, 2 \mathrm{~W}$

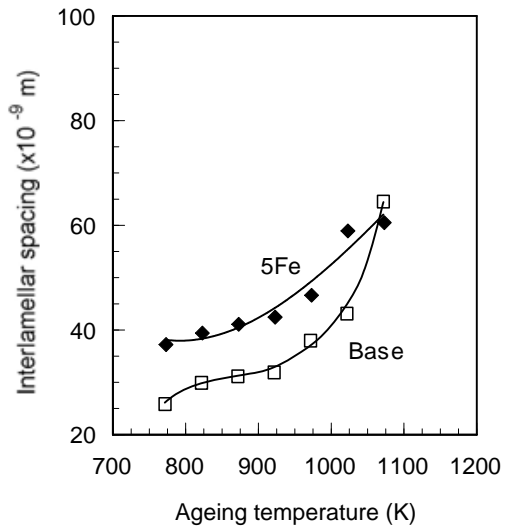

(c) $5 \mathrm{Fe}$

Fig.12. The interlamellar spacing $<\lambda>$ versus the ageing temperature for (a) 1 Mo and 2 Mo alloys, (b) $1 \mathrm{~W}$ and $2 \mathrm{~W}$ alloys and (c) $5 \mathrm{Fe}$ alloy.

\section{4. 考 察}

上述のように, Ni-Cr-Al 合金のセル状組織の成長速度は Mo，W 拉よび $\mathrm{Fe}$ の添加により変化することが判明した。 このようなセル状組織の成長速度に及ぼす添加元素の影 響については，種々の合金系に対する観察実験が行われ ている 10)〜13). また，これらの観察結果を説明するため に，原子サイズの差に起因した影響 14) 16)，原子価の違 いに起因した影響 17)，七ル界面に合金元素が偏析して拡 散の障壁となるソリュートドラッグ効果 ${ }^{18)}$ を考慮した機 構などが提案されている5),6). 特に, Manna らは, $\mathrm{Pb}-\mathrm{Sn}$ 二元系合金に少量の $\mathrm{Cd}$ や $\mathrm{Sb}$ を添加した際にセル状組織 の成長が抑制されることを実験的に観察している。 また， このような成長の抑制は, $\mathrm{Sn}, \mathrm{Cd}$ 㧍よび $\mathrm{Sb}$ の原子サイ ズや原子価に大きな差異がないことを踏まえ，ソリュー トドラッグ効果に起因していることを推測している ${ }^{19}$. 本研究に扔ける $\mathrm{Ni}, \mathrm{Cr}, \mathrm{Mo}, \mathrm{W}$ 扔よび Fe に対する原子 半径抢よび原子価を Table 2 に示す。これら 5 種類 の合金元素に扒いても，原子サイズや原子価に著しい差 異はなく，本研究で見られた Mo, W のセル成長速度の 減少は, ソリュートドラッグ効果のような機構によるも のと考えられる.

ところで, Ni-38Cr-3.8Al 合金は $\mathrm{Al}$ が $\gamma^{\prime}$ 相の生成に 消費されるため, 過飽和の $\mathrm{Ni}-\mathrm{Cr}$ 二元系として式 (2)の Aaronson and Liu モデル 20) を適用し，七ル境界の拡散挙 動を解析した2).

$$
v=4 \frac{C^{p}-C^{m}}{C^{p}-C^{0}} \frac{\delta D_{B}}{\lambda^{2}}
$$

Table 2. Atomic radii and valences of $\mathrm{Ni}, \mathrm{Cr}, \mathrm{Mo}, \mathrm{W}$ and $\mathrm{Fe}$.

\begin{tabular}{c|c|c|c|c|c}
\hline & $\mathrm{Ni}$ & $\mathrm{Cr}$ & $\mathrm{Mo}$ & $\mathrm{W}$ & $\mathrm{Fe}$ \\
\hline atomic radius $(\mathrm{nm})$ & 0.135 & 0.140 & 0.145 & 0.135 & 0.140 \\
\hline valence & 2 & 1 & 1 & 2 & 2 \\
\hline
\end{tabular}

ここで， $\delta$ はセル境界の厚さ， $\mathrm{D}_{\mathrm{B}}$ はセル境界の界面拡散 係数, $\mathrm{C}^{0}$ はマトリックス中の $\mathrm{Cr}$ 濃度, $\mathrm{C}^{\mathrm{m}}$ はセル境界で の $\alpha$ 相前面の $\mathrm{Cr}$ 濃度, $\mathrm{C}^{\mathrm{P}}$ は $\alpha$ 相の $\mathrm{Cr}$ 濃度である. 本研 究での Ni-Cr-3.8Al- $X$ 合金は多元系であるが, 簡便化のた め 2 元系と仮定し, (2) 式より見かけ上の $\mathrm{D}_{\mathrm{B}}$ の值を算出 した。すなわち, 既報と同様 ${ }^{2)}, \mathrm{C}^{0}, \mathrm{C}^{\mathrm{m}}, \mathrm{C}^{\mathrm{P}}$ の平衡 $\mathrm{Cr}$ 濃度 を Thermo-Calcより計算し, 実験で求めたセル成長速度 $v$, ラメラー間隔 $\lambda$ を(2) 式に代入した。その結果を Fig.13 に示す。ここで $\delta$ は $\mathrm{Ni}$ の格子定数である $3.6 \times 10^{-10} \mathrm{~m}$ を 適用した。さらに $\mathrm{D}_{\mathrm{B}}$ を(3)のアレニウスの式で整理し, 拡散係数の活性化エネルギー $\Delta \mathrm{H}$ を求めた結果を Table 3 に示す。

$$
D_{\mathrm{B}}=D_{\mathrm{B}(0)} \exp \left(-\frac{\Delta H}{R T}\right)
$$

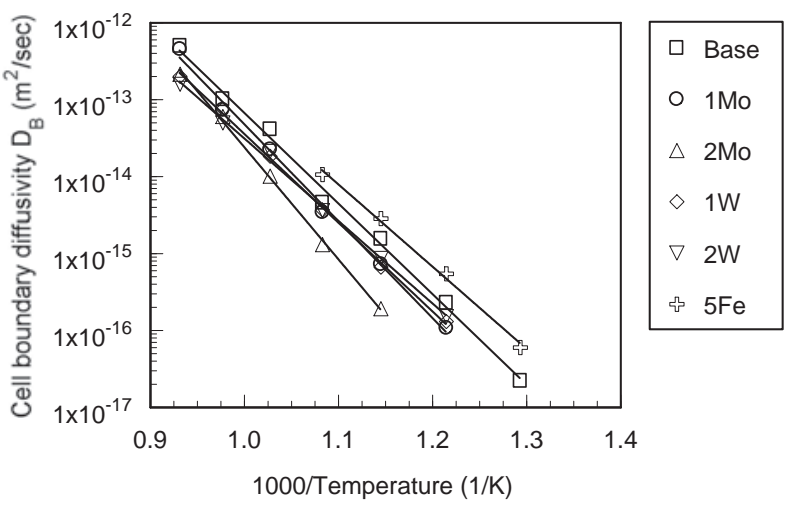

Fig.13. Arrhenius plots of cell boundary diffusivity.

Table 3. Activation energy and pre-exponential factor by Arrhenius equation of cell boundary diffusivities.

\begin{tabular}{ccc}
\hline & $D_{\mathrm{B}(0)}\left(\mathrm{m}^{2} / \mathrm{s}\right)$ & $\Delta \mathrm{H}(\mathrm{kJ} / \mathrm{mol})$ \\
\hline Base & $4.0 \times 10^{-2}$ & 225 \\
\hline $1 \mathrm{Mo}$ & $1.9 \times 10^{-1}$ & 241 \\
\hline $2 \mathrm{Mo}$ & $9.0 \times 10^{0}$ & 279 \\
\hline $1 \mathrm{~W}$ & $1.2 \times 10^{-2}$ & 221 \\
\hline $2 \mathrm{~W}$ & $1.7 \times 10^{-3}$ & 205 \\
\hline $5 \mathrm{Fe}$ & $4.5 \times 10^{-3}$ & 204 \\
\hline
\end{tabular}


$1 \mathrm{Mo}$ 合金および $2 \mathrm{Mo}$ 合金では Mo 濃度が高くなると, 活 性化エンタルピー $\Delta \mathrm{H}$ および前指数因子項の $\mathrm{D}_{\mathrm{B}(0)}$ が大き くなる.一方, $1 \mathrm{~W}$ 合金では $\Delta \mathrm{H}, \mathrm{D}_{\mathrm{B}(0)}$ とも変化は小さいが, $2 \mathrm{~W}$ 合金および $5 \mathrm{Fe}$ 合金ではどちらも小さくなっている. このように，添加元素の違いによりセル境界における拡 散挙動が変化することが示唆されるが, セル成長速度と 拡散挙動に及ぼす添加元素の影響が必ずしも一致してお らず，2元系を前提にした本モデルの単純な適用は適切 でない. そのため, 多元系での相互拡散やソリュートド ラッグ効果を考慮した界面偏析因子の項を取り入れる必 要があり,さらに詳細な検討が必要である。

\section{5. 結論}

$\mathrm{Ni}-\mathrm{Cr}-\mathrm{Al}$ 合金において, 第 4 元素添加による $\left(\gamma+\gamma^{\prime}+\alpha\right)$ セル状組織の成長抑制の可能性を検討するために, Ni(35-36) mass\% Cr-3.8 mass\%Al 合金に 1-2 mass\%の Mo, 1-2 mass\%のW， 5 mass\%の Fe を添加した Ni-Cr-Al- $X$ 合 金を $1423 \mathrm{~K}$ で固溶化加熱処理した後, 773-1073 K の温度 範囲で最長 $180 \mathrm{ks}$ の時効加熱処理した際のセル状組織成 長挙動を調査し, 以下の結論を得た。

(1) Mo およびWの添加は, セル状組織の成長を遅くする 効果がある.

(2) 上記 (1)のセル成長抑制効果は，WよりもMoにおい て顕著である.

(3) Fe の添加には，セル状組織の成長抑制効果はない.

(4) セル状組織内部の $\gamma$ 相と $\alpha$ 相のラメラー間隔は, Mo, $\mathrm{W}$ および $\mathrm{Fe}$ の添加により増加する.

$$
\text { (文 献) }
$$

1) 高畑紀孝, 植田茂紀, 清水哲也：電気製鋼，75 (2004), 97.

2) 植田茂紀, 清水哲也, H.K.D.H.Bhadeshia：電気製鋼, 77(2006), 133.

3) M. Kawase, H. Emoto and M. Kikuchi : Proc. Phase Tran. '87, University of Cambridge, Institute of Metals, edit by G.W. Lorimer, (1987), 254.

4) 霜鳥一三, 河合光雄, 野老博和 : 日本金属学会誌, 36 (1972), 685.

5) D.B. Williams and E.P. Butler : Inter. Metals Rev., 26 (1981), 153.

6) I. Manna, S.K. Padi and W. Gust : Inter. Metals Rev., 46 (2001), 2, 53.

7) P. Zieba and W. Gust : Z. Metallkd., 92 (2001), 7, 645

8) W. Gust, T. Ngun-Tat and B. Predel : Mater. Sci. Eng., 39 (1979), 15.
9) F.G. Caballero, C. Garcia-Andres and C. Capdevila : Mater. Character., 45 (2000), 1111.

10) 天野嘉次, 香山滉一郎：日本金属学会誌, 35 (1971), 261.

11) 近藤充夫, 添野浩：日本金属学会誌, 39 (1975), 817.

12) 近藤充夫, 添野浩：日本金属学会誌, 40 (1976), 419.

13) 池野進, 佐治重興, 堀茂徳: 日本金属学会誌, 40 (1976), 1105.

14) G. Kunze and P. Wincierz : Z. Metallkd., 56 (1965), 421.

15) W.C. Hagel and H.J. Beattie : Trans. AIME., 215 (1959), 967.

16) B. Predel and H. Ruge : Z. Metallkd., 59 (1968), 777.

17) B. Predel and M. Fredel : Arch. Eisenhüttenwes., 44 (1973), 395.

18) K. Lücke and K. Detert : Acta Metall., 5 (1957), 628.

19) I. Manna and S.K. Padi : Phys. Status Solidi (a), 123 (1991), 393.

20) H.I. Aaronson and Y.C. Liu : Scr. Metall., 2 (1968), 1. 